FILOZOFIA

Roč. 74, 2019, č. 1

DOI: https://doi.org/10.31577/filozofia.2019.74.1.3

\title{
OD KONFLIKTU K ZDATNOSTI. AISCHINÉS A SOKRATOVSKÁ VÝCHOVA
}

JAROSLAV CEPKO, Katedra filozofie, Filozofická fakulta Univerzity Mateja Bela v Banskej Bystrici, Banská Bystrica, SR

\author{
CEPKO, J.: From Conflict to Excellence. Aeschines and the Socratic \\ Education \\ FILOZOFIA, 74, 2019, No. 1, pp. 28 - 39
}

\begin{abstract}
Aeschines of Sphettus is a Socratic author that deserves more attention than he actually gets, as he is, besides Plato and Xenophon, the only Socratic who left substantial literary records. The present paper focuses on his representation of Socrates' educational activity. Aeschines' Socrates does not only disavow any technical capability to make the others better, but he entrusts the educational work to an unpredictable "divine dispensation" which simply means a factor that escapes the educator's control. Not unlike Alcibiades, who is the target of Socratic educational endeavor in Aeschines' dialogue, the author himself must have experienced in his life that achievement of virtue cannot be simply transferred from educator to educated, but requires a strong personal commitment.
\end{abstract}

Keywords: Socratic dialogue - Minor Socratics - Aeschines of Sphettus - Socratic education - Theia moira.

Úvod. Sokrates akiste patrí $\mathrm{k}$ postavám, ktoré $\mathrm{v}$ dejinách výchovy nemožno obíst'. Už antika identifikovala jadro jeho verejnej aktivity vo formujúcom pôsobení na aténsku mládež, čo mu na jednej strane prinieslo zástup obdivovatel'ov, no na druhej strane viedlo aj k jeho tragickému koncu. Aj dnes sa Sokratovo meno s obl'ubou spája s inovatívnymi postupmi modernej pedagogiky. Aký však naozaj bol Sokratov výchovný postup, aké metódy používal a aké ciele sledoval? Táto otázka naráža na notorický problém, ktorý $\mathrm{v}$ modernej kritike vystupuje pod názvom „sokratovská otázka“. Ak sám Sokrates programovo odmietal zverit’ svoje myšlienky písmu, čo nás vôbec oprávňuje vyjadrovat' sa 0 „historickom Sokratovi“"? Jediné, čo máme k dispozícii, sú správy z druhej (a niekedy až z tretej) ruky, správy, ktoré sú nasýtené subjektívnou recepciou skúseností ich autorov so Sokratom a boli napísané so zámermi niekedy na míle vzdialenými historicky vernej reprodukcii. Tieto rôzne obrazy vykazujú podobnosti i rozdiely. Ich pluralita je dôvodom na žial pre tých, čo ešte stále túžia po podobizni „ozajstného“ Sófroniskovho syna a po zázname jeho „skutočných“ diskusií na agore, no pre tých, čo sa chcú inšpirovat' jeho dedičstvom a neprekáža im, že toto dedičstvo nie je totožné s jeho pôvodcom, je táto pestrost' interpretácií zaiste bohatstvom. 
Najvplyvnejším z týchto obrazov bol a doteraz zostáva portrét, ktorý nám zanechal Platón. Pozornost' sa sústred’uje najmä na takzvané „rané dialógy“, o ktorých sa predpokladá, že obraz Sokrata a jeho výchovných postupov je v nich najmenej skreslený. Okrem toho sa $\mathrm{v}$ hojnej miere siaha po obraze od Xenofóna, autora, ktorý síce za Platónom zaostáva v sofistikovanosti, no $\mathrm{v}$ jeho bohatej písomnej pozostalosti má postava Sokrata svoje pevné miesto. Vieme, že písaniu

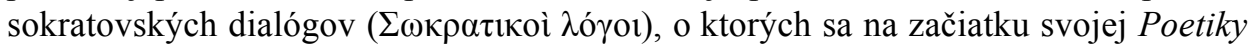
(1447b 9 - 10) ako o etablovanom žánre zmieňuje už Aristoteles, sa venovali aj iní členovia užšieho Sokratovho kruhu, no ich literárna pozostalost' sa nám, nanešt’astie, zachovala iba $\mathrm{v}$ podobe zlomkov. Z tých, ktorých Platón zaradil do zoznamu prítomných na rozlúčke so Sokratom v jeho posledný deň vo väzení (Phaed. 59b c), to platí o Antisthenovi, Eukleidovi, Faidónovi a Aischinovi. Voči poslednému z nich bola antická biografická a anekdotická tradícia pomerne skúpa, no predsa mu patrí spomedzi tejto štvorice „menších“ sokratovcov jedno štastné prvenstvo: práve z jeho sokratovských dialógov sa nám zachoval najrozsiahlejší (i ked’ stále skromný) inventár priamych zlomkov. ${ }^{1}$

1. Život $\mathbf{v}$ znamení konfliktov. O Aischinovi sa z prameňov dozvedáme, že bol rodený Aténčan z dému Sféttos. Bol Platónovým rovesníkom a podobne ako mnohých iných mladíkov, aj jeho pritiahol príklad Sokrata, takže mu už v antike

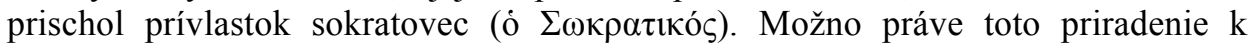
Sokratovi mu prinieslo povest' „muža, ktorý medzi Sokratovými druhmi vynikal ušl'achtilým charakterom" (Plutarch. Quom. adul. ab am. intern. 26 p. 67 E [= SSR VI A 11]). Ak však máme byt' úprimní, takéto lichotivé hodnotenie je pomerne ojedinelé a, paradoxne, v Plutarchom zachytenej sicílskej anekdote zaznieva z úst Platóna, s ktorým mal podla väčšiny prameňov vzt'ah, ktorý by sa dal označit' hocijako, len nie ako priatel'ský: Platón ho nikdy nezapája do rozhovoru so Sokratom, a hoci podla Idomenea to mal byt' práve Aischinés, kto prehováral Sokrata na útek z väzenia, Platón ho mal radšej zamenit' za Kritóna. Zdôvodnenie znie, že Aischinés „sa väčšmi priatelil s Aristippom“ (Diog. Laert. III 3 [= SSR VI A 3]). Aischinovu povest' $\mathrm{v}$ očiach väčšiny sokratovcov kazilo aj to, že $\mathrm{v}$ istom období sa mal v Aténach venovat' vyučovaniu rečníctva za peniaze (Diog. Laert. II 62 [= SSR VI A 13]). Očividne to súviselo so skutočnost'ou, že Aischinés, hoci bol

\footnotetext{
${ }^{1}$ Zbierky Aischinových zlomkov nie sú žiadnou novinkou. Prvé sa objavili už v 18. storočí. Prísnejšie kritériá a systematickejší prístup však uplatnil až H. Dittmar (1912), ktorý ponúkol aj svoju rekonštrukciu a analýzu obsahu Aischinových dialógov. O Dittmarovu zbierku, obohatenú o texty z Oxyrhinských papyrusov, ktoré boli objavené až po Dittmarovi, sa vo svojej edícii opieral aj G. Giannantoni. V jeho zbierke sokratovských pozostalostí Socratis et Socraticorum reliquiae (1990) sú Aischinove zlomky zaradené do sekcie VI A. Odkazy v tejto stati sú číslované práve podl'a tohto vydania (skratka SSR). Najnovšie vyšiel aj taliansky preklad od F. Pentassugliovej (2017). Slovenský preklad sa pripravuje ako d'alší diel série zlomkov sokratovskej tradície (Kalaš, Suvák 2013 a Cepko, Kalaš, Suvák 2016). Pri citovaní Aischinových zlomkov $\mathrm{v}$ tejto stati sa opieram o tento zatial' nezverejnený pracovný preklad Andreja Kalaša.
} 
aténskym občanom, ešte predtým, ako sa stal Sokratovým poslucháčom, upadol do chudoby. ${ }^{2}$ Chudoba sa však preňho nestala cestou $\mathrm{k}$ upevneniu vlastného charakteru ako napríklad pre Antisthena alebo aj pre samého Sokrata, ale skôr kliatbou. Nielenže za peniaze učil, čo sa jasne protiví antisofistickému obrazu sokratiky u Platóna (mimochodom, finančne slušne zabezpečeného), ${ }^{3}$ ale zháňanie peňazí sa uňho stalo priam celoživotnou vášňou. Zdá sa, že si chcel požičat' aj od Sokrata, ked' mu ten vraj ironicky odkázal, nech si „,požičiava sám od seba tým, že bude menej utrácat' za jedlo" (Diog. Laert. II 62 [= SSR VI A 13]). ${ }^{4}$ Peniaze sú udávané aj ako dôvod Aischinovej cesty do Syrakúz [SSR VI A 13 - 14], kde sa z takýchto, $\mathrm{v}$ porovnaní s Platónom menej ušlachtilých pohnútok chcel votriet' do priazne tyrana Dionýzia. C. Mársicová vyslovuje predpoklad, že príčinou Aischinovej večnej chudoby bol jeho chronický zlozvyk požičiavat'si a nevracat'. Pravdepodobne sa mu podarilo sklamat' dôveru aj najbližších priatel'ov, ked' mu nechcel požičiavat' dokonca ani Aristippos, ktorý k financiám nemal nikdy d’aleko (Mársico 2018, 216). ${ }^{5}$

Vyššie uvedené správy z anekdotickej tradície môžu i nemusia odzrkadl'ovat' historickú skutočnost'. Sú neskoré a poznačené vnútornými spormi medzi sokratovcami. Zachovalo sa nám však aj svedectvo pochádzajúce z obdobia, ked' bol Aischinés ešte nažive, a ani ono nestavia nášho sokratovca do pekného svetla. Ide o súdnu reč rétora Lysia, ktorej časti reprodukuje Athénaios (XIII 611 D - 612 F [= $S S R$ VI A 16]). Rečník v súdnom spore hovorí v mene istého Aischinovho veritel'a, ktorého Aischinés zažaloval pravdepodobne s ciel'om dosiahnut' uňho lepšie úroky; preto Lysias označuje Aischinov počin za najhorší druh sykofantérie. Ak Lysiovej reči prisúdime kredit, dozvedáme sa, že Aischinés sa snažil zohnat' kapitál na rozbehnutie voňavkárskeho biznisu, ku ktorému sa vraj dostal tak, že zviedol sedemdesiatročnú ženu voňavkára Hermaia, ktorá - ako kvetnato opisuje rečník - mala viac prstov na ruke ako zubov v ústach. Očividne podl'ahol svojmu starému neduhu, požičiaval si a nevracal. Pred jeho domom sa údajne v húfoch schádzali veritelia, susedia sa od neho st'ahovali preč, ba jeho podvody vraj zachádzali až tak d'aleko, že vyberal peniaze na dobročinné účely, no tie potom podl’a Lysia prepíjal. Rečník Aischina nešetrí a vstupuje mu do svedomia tým, že poukazuje na ostrý kontrast medzi filozofiou, ktorú verbálne vyznáva, a vlastným bezohl’adným konaním: „Myslel som si, že Aischinés, ktorý bol predsa žiakom Sokrata a o spravodlivosti a cnosti napísal tol'ko vznešených rečí, by v sebe nikdy nenašiel tol'ko drzosti, aby

\footnotetext{
${ }^{2} \mathrm{O}$ možných spoločenských dôvodoch a „protirečeniach sokratizmu“ preneseného na rôzne spoločenské vrstvy píše Plácido (2010).

${ }^{3}$ Pravdupovediac, z vyučovania rétoriky spolu s Aischinom obviňuje Favorinus aj samého Sokrata (Diog. Laert. II 20 [= SSR I D 1]); porovnaj Plácido (2010, 129).

${ }^{4}$ Azda narážka na Aischinovu obéznu postavu? K tomu pozri Mársico $(2018,216)$. Vysvetlovalo by sa tým, okrem iného, jeho priatel'stvo s hedonikom Aristippom.

5 Svedectvom toho, že z tohto alebo nejakého iného dôvodu Aischina opustili priatelia, môže byt' informácia zachovaná v Diog. Laert. II 63 [= SSR VI A 13], že mal iba jediného blízkeho priatel’a, Aristotela zvaného Mythos, o ktorom však nič bližšie nevieme.
} 
vykonal činy tých najhorších a najnespravodlivejších l’udí“ [SSR VI A 16]. Úryvky z Lysiovej reči končia rečníkovou záverečnou poznámkou, v ktorej Aischina častuje

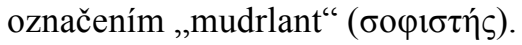

Referujúci Athénaios $\mathrm{v}$ tom istom zlomku rozširuje nelichotivú povest' podvodníka aj o pochybné autorstvo Aischinových dialógov: „Pri čítaní dialógov, ktoré sa nám zachovali pod jeho menom, ho však obdivujeme ako čestného a mierneho človeka. Celkom inak by to bolo, keby autorom spisov, o ktorých hovoríme, bol v skutočnosti mudrc Sokrates. Hovoria o tom Idomeneovi žiaci, podl'a ktorých tieto diela darovala Aischinovi po manželovej smrti Xanthippa" [SSR VI A 16]. Podozrenie z plagiátorstva alebo krádeže textov sa objavuje aj $\mathrm{v}$ iných prameňoch [SSR VI A 22, 28]. Inde sú zasa Aischinove spisy chválené za čistotu a jasnost' štýlu [SSR VI A 24, 29, 33]. Aelius Aristides, rečník z obdobia takzvanej druhej sofistiky, ktorý je pre nás dôležitým zdrojom zlomkov z Aischinových spisov, sa pokúša tento rozpor vysvetlit'. Podl’a neho podozrenie, že Sokratov žiak nechal kolovat' pod svojím menom spisy, ktoré v skutočnosti napísal jeho učitel', mohlo vzniknút' na základe toho, že tieto spisy ,pripadali všetkým také blízke a vlastné Sokratovej povahe, že l'ahko vznikol priestor pre takúto domnienku“. Viera, že Aischinove spisy ponúkajú neskreslený obraz Sokrata, žije aj u súčasných komentátorov. J.-A. Mallet $(2013,231)$ argumentuje tým, že Aischinés nemal ambíciu budovat' vlastnú „sokratovskú školu“, teda nemal záujem ani o to, aby svojho literárneho Sokrata využíval na propagáciu vlastných názorov. Preto podl’a neho možno predpokladat', že Aischinove zlomky obsahujú cenné autentické svedectvo o Sokratovej filozofii a jeho konaní. ${ }^{6}$

Dodajme iba tol'ko, že naháňat' sa za historickým Aischinom by bolo ešte márnejším úsilím ako pátrat' po historickom Sokratovi. Nevieme, do akej miery rečník Lysias skutočnost' reprodukuje a do akej miery ju z pochopitel'ných dôvodov prekrúca a prifarbuje. Rovnako nevieme ani to, kol'ko pravdy je na Aischinových problematických vzt'ahoch s ostatnými sokratovcami. Isté však je, že pramene nám podávajú obraz o Aischinovom živote pretkanom konfliktmi. Nezdá sa, že by to bol alter Socrates; svojím správaním pravdepodobne robil sokratovským ideálom skôr hanbu. Ako je teda možné, že - ako tvrdí aj sám jeho rival Lysias - napísal tol'ko krásneho a vznešeného o zdatnosti? Išlo o pokrytca, čo v spisoch káže vodu cnosti a vo svojom konaní pije víno prospechárstva? Ak pristúpime k zachovaným útržkom textov bez snahy vidiet' $v$ nich tvár Sokrata, možno v nich naopak nájdeme tvár Aischina. Udalost' stretnutia so Sokratom ho bezpochyby nejako poznačila a tým, že sa rozhodol o ňom písat', ponúka svoje vlastné videnie tejto udalosti; odhal'uje nám,

\footnotetext{
${ }^{6} \mathrm{Na}$ margo poznamenajme, že podl'a Athénaia (XI 507 C [= SSR VI A 21]) Aischinés nejakého žiaka predsa len mal, a to Xenokrata, ktorého mu údajne neskôr „ukradol“" Platón. Okrem neho možno bol jeho žiakom aj Aristoteles Mythos spomenutý v poznámke č. 5 (Diog. Laert. II 63 [= SSR VI A 13]). Navyše Ch. Kahn z anachronizmov v Aischinových zlomkoch vyvodzuje, že jeho Sókratikoi logoi sú v rovnakej miere fiktívne ako diela jeho rovesníkov zo Sokratovho okruhu $(1996,28)$.
} 
čo Sokrates znamenal pre neho samého. Ako to výstižne sformulovala C. Mársicová, „Aischinés je kontroverzná postava, ktorá pracuje s kontroverznými postavami“ $(2018,211$ - 212). Vo svojich spisoch nám ukazuje Sokratov výchovný vplyv na osoby, ktoré majú $\mathrm{k}$ zdatnosti rovnako d'aleko ako autor, osoby vnímané rozporuplne až škandalizujúco $\mathrm{v}$ dobovej spoločnosti, no indikuje aj hlbší konflikt v ich vnútri, a to je podl’a Aischina práve pole Sokratovho pedagogického zákroku.

2. Prípad Alkibiadés. Od povýšenectva k slzám. Katalóg Aischinových sokratovských spisov obsahuje sedem dialógov: Miltiades, Kallias, Axiochos, Aspasia, Alkibiadés, Télauges a Rhinón (Diog. Laert. II 61 [= SSR VI A 22]). ${ }^{7}$ Najviac textu sa zachovalo z dialógov Alkibiadés a Aspasia, vd'aka čomu možno podat' celkom plauzibilnú rekonštrukciu ich obsahu. V obidvoch prípadoch je nosnou témou nadobudnutie zdatnosti ( $\alpha \rho \varepsilon \tau \eta ́)$, čo možno pokladat' za štandardný ciel' sokratovskej výchovy. V Alkibiadovi je paidagógom sám Sokrates, v Aspasii Sokrates odporúča boháčovi Kalliovi, aby svojich synov zveril do výchovy hetére Aspasii, ktorá Aténam už „,vychovala“ dvoch zdatných štátnikov - Perikla a Lysikla.

Obrát'me pozornost' k dialógu Alkibiadés. Postava tohto Sokratovho „miláčika“

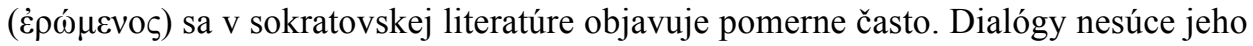
meno nachádzame v katalógoch spisov Eukleida, Faidóna, Antisthena a samozrejme u Platóna. Tento arogantný mladík, neskorší rúhač a vlastizradca, bol pravdepodobne citovaný ako jeden $\mathrm{z}$ frapantných prípadov Sokratovho zhubného vplyvu na mládež v Polykratovej Obžalobe. ${ }^{8}$ Reakcia sokratovcov poukazovala na to, že Sokratova výchova tieto negatíva nezapríčinila, ale naopak, na nejaký čas ich držala pod kontrolou (Dittmar 1912, 164; Giannantoni 1990, 4. zv., 349; Kalaš, Suvák 2013, 129). U Aischina sa okrem rovnomenného dialógu Alkibiadés objavuje prinajmenšom aj v Axiochovi [SSR VI A 56].

Poradie zlomkov, ktorého sa vo svojej edícii pridržiava aj G. Giannantoni, navrhol už H. Dittmar (1912, 97 - 120). Podl'a tejto rekonštrukcie ide o nepriamy, diegetický dialóg, v ktorom Sokrates referuje o svojom dávnejšom rozhovore s Alkibiadom nám neznámemu, v zachovaných zlomkoch neuvedenému poslucháčovi, alebo celému kruhu poslucháčov (Pascalau 2013, 233). Alkibiadés je ešte mladý, všetky excesy, ktoré ho urobili neslávne známym, má ešte pred sebou. No už teraz je

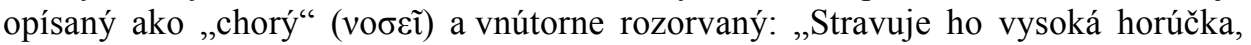
ktorá ho privádza do šialenstva a od základu otriasa jeho zdravým rozumom“

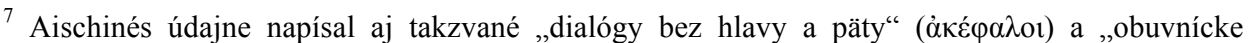

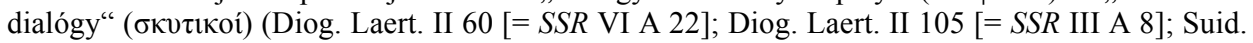

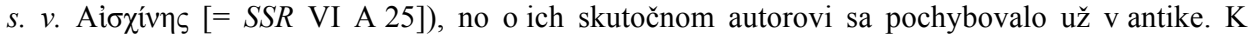
„obuvníckym dialógom“ a postave Simóna Obuvníka, údajného prvého autora Sókratikoi logoi (Diog. Laert. II 123 [= SSR VI B 87]); porov. Sellars (2003).

${ }^{8}$ Text Obžaloby, ktorú Polykrates napísal ako fiktívnu reč takmer desat'ročie po procese so Sokratom, sa nám, žial', nezachoval, no od Isokrata (Busir. 5) vieme, že sa v nej písalo aj o Alkibiadovi.
} 
(Maxim. Tyr. Philosoph. VII 7 [= SSR VI A 42]). Mladíkova choroba je metaforou ambícií, ktoré ho zožierajú a ktoré nedokáže spracovat' inak ako domýšlavým, arogantným a povýšeneckým správaním (Cicer. Tusc. disp. III, 32, 78 [= SSR VI A 52]). Pohŕda nielen svojím tútorom Periklom, ale jeho „pýcha“ ( $\rho \circ$ prí $\mu \alpha \tau o \varsigma$ $\pi \varepsilon \rho ı \tilde{v}$ ) siaha až tak vysoko, že by bol schopný kritizovat' aj olympských bohov (Ael. Aristid. De quatt. 575 [= SSR VI A 46]).

Sokrates túto megalomanskú „chorobu“ diagnostikuje a podujíma sa ju liečit'. V porovnaní s inými obrazmi Sokrata vychovávatel’a, najmä s Platónovým, však treba poznamenat', že Sokratova terapia v Aischinovom podaní nevyužíva, ako by sme očakávali, výmenu krátkych otázok a odpovedí, ale postupuje prostredníctvom konfrontácie so životnými príkladmi iných osobností. Tieto príklady sú rozvinuté do obsiahlych pasáží, v ktorých si má čitatel' povšimnút' podobnosti a rozdiely medzi porovnávanými životmi a na ich základe vycítit', kam Sokrates vôbec mieri. Túto zál'ubu v ilustrovaní vlastného myšlienkového postupu rozsiahlymi príkladmi (a platí to nielen o themistoklovských pasážach v Alkibiadovi, ale aj o príkladoch pololegendárnych žien Rhodogyné a Thargélie v Aspasii) B. Ehlersová označuje za Aischinov špecifický autorský postup $(1966,44)$. Mohlo by to naznačovat', že Aischinés, sám nejaký čas učitel' rečníctva [SSR VI A 13], zostal kdesi na polceste medzi rétorikou a sokratizmom (Plácido 2010, 124). Zároveň ide o indíciu, že Aischinés ako autor ráta so spoluprácou čitatel'a a kladie naňho interpretačné nároky. Jeho literárny Sokrates tak pedagogicky nepôsobí iba na dramatis personae, ale má možnost' formovat' aj toho, kto tento proces sleduje a sprítomňuje vnímavým čítaním.

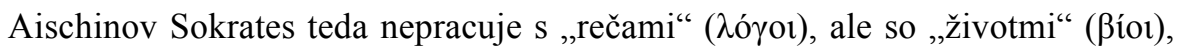
a to vel'mi bezprostredne. Zásah do Alkibiadovho charakteru sa deje priam psychoanalyticky. Sokrates si všimne, že Alkibiadés napriek svojmu všeobecnému povýšeneckému postoju skryto obdivuje štátnika Themistokla. Navonok ho síce kritizuje rovnako ako ostatných (Ael. Aristid. De quatt. 348 [= SSR VI A 50]), no v

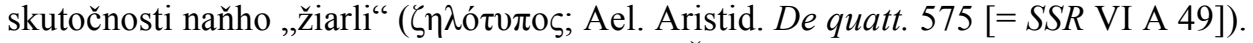
Mladíkovo vnútro je poznačené konfliktom. Žije v ilúzii vlastnej nadradenosti, no zároveň naráža na vedomie, že je tu niekto „lepší“. Sokrates toto napätie nemierni, ale naopak, vyostruje. Tým, že Alkibiadovi nemilosrdne pripomína, že Themistoklovi je naozaj čo závidiet', vyvoláva v ňom „narcistické zranenia“ (Mársico 2018, 205). Žiarlivost' Sokratovho partnera pravdepodobne len rastie, ked' má pred očami obraz Themistokla, ktorý nielenže dosiahol štátnický a vojenský úspech, ale vlastnou šikovnost'ou sa vedel zabezpečit' aj pred prípadnými nepredvídatel'nými zvratmi osudu, ked' sa pred Xerxom nepravdivo označil za toho, kto mu umožnil bezpečný útek po porážke pri Salamíne. Tento trik mu potom poslúžil na získanie král'ovej priazne, ked' sa po ostrakizovaní Aténčanmi dostal do Perzie (Ael. Aristid. De quatt. 348 - 349 [= SSR VI A 50]; porovnaj Herod. VIII 108 - 110; Thuc. I 137, 4).

Ked' Alkibiadova žiarlivost' takto postupne prerastá do túžby sformovat' svoj život podl'a Themistoklovho vzoru, Sokrates mu uštedruje d’alší úder: ani 
Themistoklés nepatril k tým, ktorým by sa vo všetkom darilo. Politická múdrost'

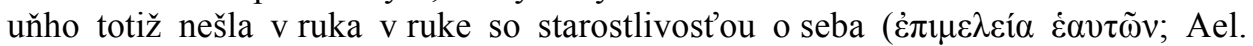
Aristid. De quatt. 348 - 349 [= SSR VI A 50]). Ciel', ktorý mladík už-už videl pred sebou, sa zrazu mení v paru, a on si začína uvedomovat', že ani urodzený pôvod, ani prirodzené nadanie ho nerobia „dobrým“. Ciel' „stat' sa lepším“, ktorý mu Sokrates predostiera ako životný program, sa mu javí ako niečo vel'mi vzdialené, ba až nedosiahnutel'né. Preto „celý zronený prepuká v plač s hlavou zloženou na kolenách“ (Ael. Arist. De quatt. 576 [= SSR VI A 51]) a „so slzami v očiach prosí Sokrata, aby mu odovzdal cnost' (ut sibi virtutem traderet) a zobral zlý charakter (turpitudinemque depelleret)“(Cicer. Tusc. disp. III 32, 77 [= SSR VI A 52]).

3. Čo ani Sokrates nezmôže. Čo sa v dialógu odohráva d’alej, nie je celkom jasné. Dokumentovatel'ným výsledkom je to, že Alkibiadés spozná vlastnú situáciu

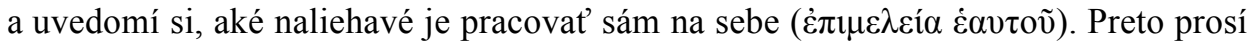
Sokrata, aby zasiahol. Výsledok je teda pomerne skromný: je to mladíkovo sebapoznanie a túžba dat' sa vychovat'. Cicerónove slová turpitudinem depellere a virtutem tradere sú $\mathrm{v}$ zásade dvoma stránkami tej istej mince - aktu výchovy,

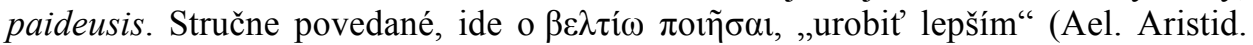
De rhet. I 74 [= SSR VI A 53]). Namieste je však otázka: dosiahol Sokrates tento transfer zdatnosti? Cicero interpretuje mladíkovu chorobu, o ktorej bola reč na samom začiatku, ako chorobu morálnu: „Pozostávala z chorôb a nedostatkov duše (ex animi malis vitiisque constabat)“" (Cicer. Tusc. disp. III 32, 78 [= SSR VI A 52]). Každý Aischinov čitatel' vie, že táto choroba zostala nevyliečená a neskôr prepukla aj navonok. Stat' sa výkladnou skriňou sokratovskej areté sa Alkibiadovi nikdy nepodarilo. Je teda Aischinés kronikárom Sokratovho vychovávatel'ského fiaska?

Nevieme, čo sa v dialógu odohrá od momentu, ked’ sa Alkibiadés rozplače a prosí Sokrata o pomoc. Aelius Aristides nám zachoval už iba sériu citátov z jeho záveru (De rhet. I 61 - 64 a 74 [= SSR VI A 53]). Alkibiadés už nie je prítomný9 a Sokrates svoje slová adresuje poslucháčom, ktorým referuje o svojom rozhovore s mládencom. Je možné, že to robí s dlhším časovým odstupom. ${ }^{10}$ Pre nás je však dôležité, že Aischinov Sokrates ponúka reflexiu nad tým, čo sa odohralo, a nad svojím vlastným príspevkom. Jeho prvý komentár obsahuje vyznanie nevedomosti, s akým sa stretávame aj u Platónovho Sokrata, príznačne v Obrane (21d): „Keby

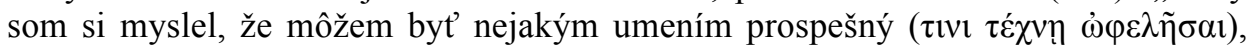
sám by som sa obvinil z vel'kej nerozumnosti $(\mu \omega \rho$ pí $)$. V tomto prípade som si však myslel, že mi to bolo dané nejakým božím údelom ( $\theta$ cía $\mu$ oípą), aby som mohol čelit' Alkibiadovi. A nič z toho nie je vôbec čudné.“ Ak predpokladáme, že Aischinés (podobne ako Platón) píše svoj dialóg v reakcii na Polykratovu Obžalobu, ide o rovnaký t’ah, akým sa v Obrane Platónov Sokrates vyhýba obvineniu z kazenia

\footnotetext{
9 Podl'a Giannantoniho rekonštrukcie mal Alkibiadés scénu opustit' hned', ked' si s plačom uvedomil svoju morálnu nedostatočnost' (1990, 4. zv., 588).

${ }^{10}$ Nasvedčovali by tomu imperfektá použité $\mathrm{v}$ posledných vetách dialógu citovaných Aeliom.
} 
mládeže. Nie je totiž $\mathrm{v}$ „technickom“ zmysle učitel’om, a teda nemá ani žiakov, ktorých by vedome mohol kazit'. Sokrates nemá žiadnu techné, ktorú by mohol kedykol'vek vytiahnut' z rukáva, aby niekomu výchovne prospel. Alternatívou k techné je však „božský údel“, theia moira. J.-A. Mallet (2013, 228 - 229) upozorňuje na paralely s Platónovou Obranou, kde Sokratovo pôsobenie na aténsku polis je tiež pripisované theia moira, ba celý svoj život Sokrates pred súdom interpretuje ako službu bohu (30a). ${ }^{11}$ Nazdávam sa však, že netreba chodit' tak d'aleko a že theia moira je prostým výrazom pre niečo, čo nie je automatické, ale obsahuje v sebe prvok kontingencie. ${ }^{12}$ Sokrates teda pripúšt’a, že jeho slová môžu prospievat', no tento účinok nie je samozrejmý, ale závisí od nepredvídatel'ného a nenárokovatel'ného faktora. Ak je teda Sokratovo pôsobenie účinné, nie je to z jeho vlastnej moci, ale vd'aka niečomu, čo sa vymyká jeho kontrole. Aischinés zrejme cítil, že tento rozdiel treba lepšie priblížit', preto - stále v tom istom zlomku z Aelia - vkladá do úst svojho Sokrata túto analógiu: „Ved' mnohí chorí sa uzdravili nielen l'udským umením ( $\alpha v \theta \rho \omega \pi i v \eta n ~ \tau \varepsilon ́ \chi v \eta ̣)$, ale aj vd’aka št’astnému osudu, ktorý im

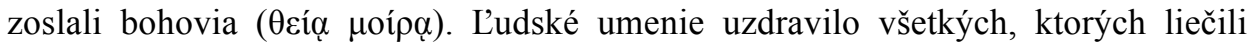

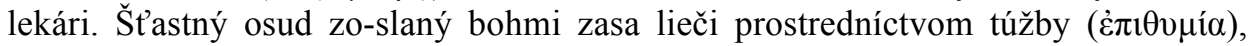
ktorá vedie l'udí $\mathrm{k}$ tomu, čo im má prospiet'. Tak napríklad, vracat' sa im chce vtedy, ked' im má vracanie pomôct'. A podobne aj na pol'ovačku sa vyberú vtedy, ked' im má prospiet', aby sa poriadne zapotili.“ Analógia je jasná: lekárske umenie (v ideálnom prípade) pomáha každému automaticky, náhodný osud vylieči iba niektorých, a to na základe toho, že sa $\mathrm{v}$ nich nepredvídatel'ne prebudí akési vnútorné pudenie.

Táto nesamozrejmá žiadost' ( $\dot{\pi} \imath \theta v \mu i ́ \alpha)$ tvorí most k Sokratovým slovám, ktoré Aelius označuje za posledné vety dialógu: „Láska, ktorou som sa zalúbil do Alkibiada, mi umožnila zažit' niečo vel'mi podobné, ako sa stáva bakchantkám. Ked' ich zachváti božské nadšenie, vedia čerpat' nie vodu, ale med a mlieko zo studní, ktoré zostávajú pre ostatných l’udí celkom suché. A naozaj, skutočne som nemal žiadne poznatky, ktoré by som mohol niekomu odovzdat' a takto byt' užitočný. Napriek tomu som bol presvedčený, že iba jednoduchým stretávaním s ním by som ho mohol urobit' pôsobením lásky lepším“ (Ael. Aristid. De rhet. I 74 [= SSR VI A 53]). ${ }^{13}$ Ide

\footnotetext{
${ }^{11}$ Keby sme prijali takúto náboženskú interpretáciu, zaujímavé by bolo preskúmat' vzt'ah medzi theia moira a daimonion (na tento problém poukazuje aj Mallet 2013, 229 - pozn. 9 - a vyslovuje sa proti ich stotožneniu). Náboženský rozmer Sokratovej aktivity vo svojej dizertačnej práci podrobne rozobral F. Škvrnda (2016).

${ }^{12}$ Podobne rapsód Ión v rovnomennom Platónovom dialógu nadobúda svoju znalost' iba vd’aka theia moira, a práve preto je „netechnický“ ( $\mu$ ๆ $\tau \varepsilon \chi v ı \kappa o ́ \varsigma) ~(542 b)$, a aténski štátnici podl’a dialógu Menón vedú obec správne nie na základe nutnej epistémé, ale náhodnej správnej / pravdivej mienky (99c). Porov. Cepko, Wollner (2014, 21 - 22).

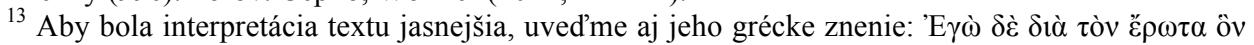

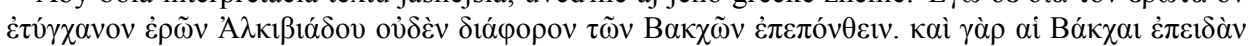

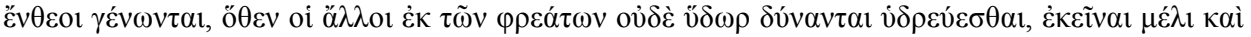

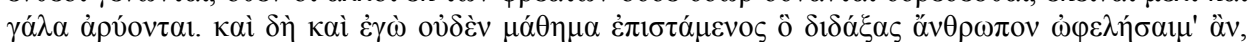


azda o najcitovanejšiu a najkomentovanejšiu Aischinovu pasáž. Najmä po publikovaní Ehlersovej monografie (1966) sa motív erosu stal u komentátorov najmarkant-nejšou charakteristikou Aischinovho Sokrata a možno ho sledovat' tak v Alkibiadovi, ako aj v Aspasii. ${ }^{14}$

Sokratova záverečná poznámka sa začína i končí zmienkou o láske. Otázka

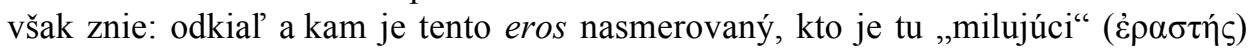

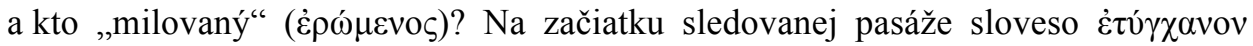

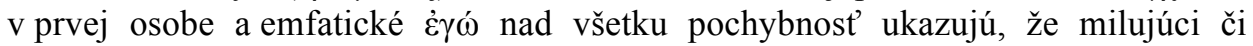
zal'úbený je Sokrates a Alkibides je milovaný. Gramatika výrazu na konci celého

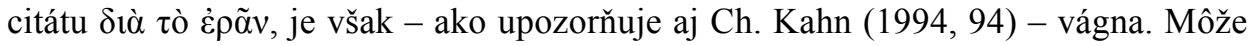
znamenat' bud' „pôsobením lásky Sokrata k Alkibiadovi“ alebo „pôsobením lásky Alkibiada k Sokratovi“. Navyše, v poslednom súvetí sa objavuje hypotetické ớv. Inak povedané, Sokrates uzatvára celý dialóg konštatovaním, že sám miluje Alkibiada a chce mu byt' osožný svojou výchovou. Naráža však na faktor, ktorý je rovnako nepredvídatel'ný a nenárokovatel'ný ako bakchický enthúsiasmos. Toto prirovnanie k bakchantkám, ktoré je prítomné aj v Platónovom Iónovi (534a), nás vracia do kontextu theia moira - Sokrates v Aischinovom Alkibiadovi môže, ale nemusí mat' schopnost' výchovne pôsobit', tak ako Ión u Platóna môže, ale nemusí vykladat' a chválit' Homéra vd'aka „netechnickému“ božskému zásahu, nad ktorým sám nemá moc. Sokrates si je istý, že sa zalúbil do Alkibiada. To však nestačí. Je potrebné, aby sa aj Alkibiadés nechal viest' erosom, teda aby sa zalúbil do Sokrata. A nad tým Sokrates nemá moc. Jeho výchovný zásah bude preto užitočný, iba ak sa z milovaného stane milujúci, čo Sokrates ponecháva ako otvorenú možnost'. Tá však predpokladá Alkibiadovo silné rozhodnutie „stat' sa lepším“. Sokrates by mohol

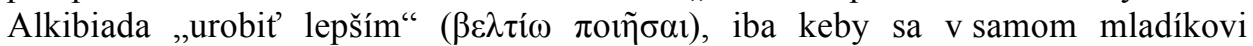
prebudila túžba „stat' sa lepším“, liečivá epithymia, o ktorej bola reč v lekárskej analógii. Nevyhnutnou podmienkou na získanie zdatnosti je teda to, aby sa z milovaného stal milujúci, čiže prevrátenie rolí, aké medzi Alkibiadom a Sokratom opisuje Platón v Sympóziu a Alkibiadovi I. Aischinés necháva Alkibiada stát' na prahu - všetko závisí od toho, či sa mladík rozhodne svoju túžbu stat' sa lepším pretavit' na čin.

To, že u Aischina nejde o ojedinelý prípad, ale o myšlienku, ktorá mu ako autorovi nedala pokoj, možno doložit aj pasážou z jeho Aspasie. Ide o pasáž, v ktorej táto „učitel'ka zdatnosti“ vedie rozhovor s Xenofónom a jeho manželkou. ${ }^{15}$ Sprievodcom je nám opät' Cicero (De invent. I 31, 51 - 53 [= SSR VI A 70]). Ten cituje Aischinovu pasáž ako príklad „indukčného“ postupu, ktorý definuje ako

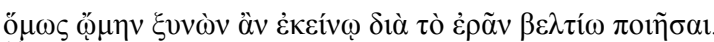

${ }^{14}$ Porovnaj Kahn (1994), Mársico (2018). Döring naproti tomu pokladá motív erosu u Aischina za preceňovaný $(1984,21$ - 22). Vel'mi podnetnú interpretáciu funkcie, ktorú plní eros v sokratovskej literatúre, ponúkla vo svojej dizertačnej práci Z. Zelinová (2018).

${ }^{15} \mathrm{Na}$ túto súvislost' poukázal K. Döring a s istou dávkou špekulácie tú istú schému predpokladá aj v d'alších Aischinových dielach $(1984,23-27)$. 
argumentáciu na základe podobnosti, pri ktorej je spoludiskutujúci na základe toho, o čom nepochybuje, nútený pripustit' to, o čom spočiatku pochyboval. Témou rozhovoru Aspasie s manželmi je otázka, či sa navzájom skutočne milujú. Aspasia sa pýta: „Predstav si, Xenofónova manželka, že tvoja susedka by mala ovel’a krajší zlatý šperk ako ty sama. Povedz mi, prosím, úprimne, či by si radšej chcela jej šperk, alebo ten svoj.“ Ked’ Xenofónova žena povie, že by samozrejme chcela susedkin krajší šperk, Aspasia sa d’alej pýta na drahé šaty. Reakcia je rovnaká. A keby susedka mala lepšieho manžela? Odpoved'ou je ženino zapýrenie. Podobne Aspasia postupuje s Xenofónom, ked' sa ho pýta najprv na susedovho koňa, potom na susedovo pole a napokon na susedovu ženu. Xenofón sa pri poslednej otázke nezmôže na slovo. Aspasia uzatvára: ,Je jasné, že aj ty, manželka, chceš mat’ toho najlepšieho muža, a práve tak aj ty, Xenofón, chceš mat' tú najlepšiu ženu. Preto keby ste to $\mathrm{v}$ živote nedosiahli - totiž stav, že už nikde na svete pre vás dvoch neexistuje lepší muž alebo lepšia žena - zaiste by ste ešte stále intenzívne hl'adali práve to, čo považujete za najlepšie.“ Manželkin rumenec a Xenofónovo zahanbené mlčanie sú podobné Alkibiadovým slzám. Zistujú, že to, čo je na nich hodné milovania, je ich zdatnost'. Ak chcú byt' dobrými partnermi, je na nich, aby svoju túžbu byt pre druhého čo najlepším premenili na skutok. Od Ciceróna sa nedozvedáme - a pravdepodobne by sme sa to nedozvedeli ani od Aischina - či sa to páru podarilo. Vlastnia iba počiatočné sebapoznanie a je na ich rozhodnutí, či sa podl'a neho budú aj správat'. Aspasia, čiže Sokrates v ženskom rode, opät' vyvoláva vnútorný konflikt, aby ho u manželov využila na prebudenie túžby stat' sa čo najlepšími.

4. Autor v koži čitatel'a. Dôvody, prečo sokratovci tak intenzívne rozoberali vzt'ah medzi Sokratom a Alkibiadom, boli naznačené vyššie. U Aischina k nim však pristupuje ešte jeden, nemenej dôležitý. Je to podobnost' životných osudov oboch týchto Sokratových žiakov, ${ }^{16}$ podobnost', ktorá bije do očí aj napriek priepastným rozdielom. Sokrates stavia pred Alkibiada príklad Themistokla, pretože ich osudy kariéra štátnika a následné vyhnanstvo - si boli podobné. Aischinés analyzuje Alkibiadov vnútorný stav, pretože s ním cíti hlbokú spriaznenost': napriek tomu, že jeden je aristokrat, boháč a úspešný politik, zatial čo druhý iba obyčajný muž z l'udu, ktorý navyše celý život smrdí grošom, obaja sú l'ud'mi vel'kých ambícií, obaja na svojej životnej ceste stretli Sokrata a pocítili v sebe túžbu stat' sa lepšími, obaja sú však morálne „chori““ a na ceste dosahovania sokratovskej areté kontinuálne zlyhávajú.

Aischinés bol Sokratov ,priatel““, غ̇ंaĩpo (Ael. Aristid. De quatt. 348 [= SSR VI A 10]), dokonca z užšieho kruhu, ak môžeme verit' Platónovi, že bol medzi prítomnými na súde i vo väzení. Na rozdiel od Alkibiada však nebol jeho miláčik

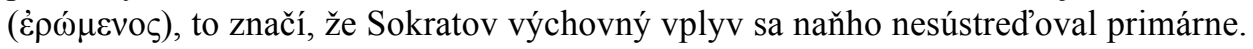

\footnotetext{
${ }^{16}$ Túto podobnost' si podrobnejšie všíma Mársico (2018, 215 - 218).
} 
Aischinés čerpal úžitok zo Sokratovej výchovy tým, že bol divákom, pozoroval jeho aktivitu, takpovediac ho čítal. A svoju lektúru Sokrata chcel odovzdat' d'alej, pričom sprostredkúval to, čo naňho urobilo najväčší dojem. Bol teda pri tom, ked' Sokrates ukazoval cestu $\mathrm{k}$ zdatnosti, cítil, že aj preňho, diváka, z toho plynie životný apel a je na ňom samom, či svoj život náležite transformuje. A to je presne situácia, v akej sa ocitá čitatel' Sókratikoi logoi. Ponúka sa mu šanca pokročit' k zdatnosti, ale tá nie je

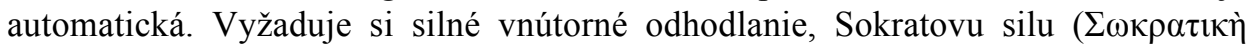

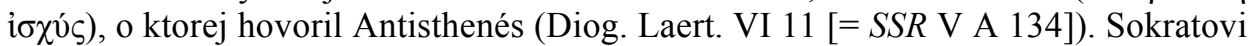
žiaci Alkibiadés i Aischinés - podl'a toho, čo vieme o ich životnej praxi - na tejto ceste za sokratovskou zdatnost'ou zlyhali. Aischinés však vo svojom obraze Sokratovho výchovného pôsobenia ukazuje, že čitatel' má možnost' zachovat' sa inak -neprežit' svoj život ako autor, ale lepšie.

Záver. Hl'adanie tváre vychovávatel'a Sokrata v Aischinových zlomkoch nás priviedlo k prekvapujúcim výsledkom. Sokratova činnost', ktorá má za ciel' urobit' druhého lepším, je nanajvýš minimalistická: „urobit’ lepším“ totiž pre Aischinovho Sokrata značí doviest' vychovávaného k uznaniu, že sa potrebuje o seba starat'. Tu sa Sokratov výkon končí a celý zvyšok, tá najväčšia čast' putovania za zdatnost'ou, už nie je $\mathrm{v}$ jeho rukách, ale závisí od faktora, ktorý sa môže, ale nemusí prejavit'. Zdá sa, že Aischinés, ktorý vo svojom živote azda až bolestne pocitoval, že každý nedisponuje takou silou charakteru, akú mal Sokrates, a nestačí poznat' krásny ideál, ale treba sa oň aj usilovat', zanechal vo svojich spisoch obraz Sokrata, ktorý odporuje obrazu Sokrata ako etického intelektualistu, aký z Platónových diel vyčítal Aristoteles. Zdá sa, že už tu, stáročia pred Augustínom, Aischinés v uvažovaní nad Alkibiadovými slzami začína $\mathrm{v}$ otázke dosahovania l'udského dobra doceňovat' rolu vôle.

\section{Literatúra}

CEPKO, J., KALAŠ, A., SUVÁK, V. (2016): Diogenis fragmenta / Diogenove zlomky. Bratislava: Vydavatel'stvo Univerzity Komenského.

CEPKO, J., WOLLNER, U. (2014): Prooimion dialogu. In: Havlíček, A. - Jinek, J. (eds.): Platónův dialog Ión. Praha: OIKOYMENH, 15 - 27.

DITTMAR, H. (1912): Aischines von Sphettos. Studien zur Literaturgeschichte der Sokratiker. Berlin: Weidmannsche Buchhandlung.

DÖRING, K. (1984): Der Sokrates des Aischines von Sphettos und die Frage nach dem historischen Sokrates. Hermes, 112 (1), 16 - 30.

EHLERS, B. (1966): Eine vorplatonische Deutung des sokratischen Eros. Der Dialog Aspasia des Sokratikers Aischines. München: Beck.

GIANNANTONI, G. (1990): Socratis et Socraticorum Reliquiae. 4 vol. Napoli: Bibliopolis (skratka $S S R$ ).

KAHN, Ch. (1994): Aeschines on Socratic Eros. In: Vander Waerdt, P. A. (ed.): The Socratic Movement. Ithaca: Cornell University Press, 87 - 106. 
KAHN, Ch. (1996): Plato and the Socratic Dialogue. Cambridge - New York - Melbourne: Cambridge University Press.

KALAŠ, A., SUVÁK, V. (2013): Antisthenis fragmenta / Antisthenove zlomky. Bratislava: Vydavatel'stvo Univerzity Komenského.

MALLET, J.-A. (2013): The Notion of theia moira in Aeschines of Sphettus' Fragments. In: Luise, F. de - Stavru, A. (eds.): Socratica III. Studies on Socrates, the Socratics, and the Ancient Socratic Literature. Sankt-Augustin: Academia, 225 - 232.

MÁRSICO, C. (2018): Shock, Erotics, Plagiarism, and Fraud: Aspects of Aeschines of Sphettus' Philosophy. In: Stavru, A. - Moore, Ch. (eds.): Socrates and the Socratic Dialogue. Leiden - Boston: Brill, $202-220$.

PASCALAU, G. (2013): Honig und Milch aus vertrockneten Brunnen: Eine dionysische Metapher bei Platon und Aischines von Sphettos. In: Luise, F. de - Stavru, A. (eds.): Socratica III. Studies on Socrates, the Socratics, and the Ancient Socratic Literature. Sankt-Augustin: Academia, $233-243$.

PENTASSUGLIO, F. (2017): Eschine di Sfetto. Tutte le testimonianze. Turnhout: Brepols.

PLÁCIDO, D. (2010): Esquines de Esfeto: las contradicciones del socratismo. In: Rossetti, L. Stavru, A. (eds.): Socratica 2008. Studies in Ancient Socratic Literature. Bari: Levante editori, $119-133$.

SELLARS, J. (2003): Simon the Shoemaker and the Problem of Socrates. Classical Philology, 98 (3), $207-216$.

ŠKVRNDA, F. (2017): Sókratova filozofia v kontexte gréckej náboženskej tradície. Dizertačná práca. Bratislava: FF UK.

ZELINOVÁ, Z. (2018): Antická paideia v sókratovskej tradícii myslenia. Dizertačná práca. Bratislava: FF UK.

Štúdia je súčast’ou riešenia grantovej úlohy VEGA: 1/0017/17 Aischinés a sokratovský dialóg.

Jaroslav Cepko

Katedra filozofie

Filozofická fakulta UMB

Tajovského 40

97401 Banská Bystrica

Slovenská republika

e-mail: jaroslav.cepko@umb.sk 